\title{
Editorial: So you want to be a Jedi? Advice for conservation researchers wanting to advocate for their findings
}

\author{
E. C. M. Parsons
}

Published online: 4 June 2013

(C) AESS 2013

It is a common occurrence among environmental science and conservation biology students or researchers; after spending years studying environmental issues and collecting data on harmful pollutants or declining species, they want to do something about it. They want to stop extinction or warn the public about the survival threats they have identified. But too frequently, the academic community insists that researchers must simply publish their research and then stand back and let others use it for advocacy.

It has been suggested that the average readership of a zoological paper is fewer than half a dozen people (Wagner and Walker 2005), and this is the average. Many papers will be read by fewer people than that. The most frequently cited recent paper in the journal Conservation Biology (Sutherland et al. 2009) had an average of 22 citations a year, which is apparently $50 \%$ higher than the next most frequently cited paper for that journal (and in turn, the journal Conservation Biology has the highest impact factor in its field). So, if just a couple dozen citations are considered to be high readership and high impact within the academic community (let alone the public), how is your study going to get to the ears of the people who count?

Basically, you have to get out there and sell it yourself. No one else will do it. You have to advocate for your view. Certainly, those causing conservation problems are advocating theirs - the logging or oil companies destroying forests and the chemical companies leaching toxins have lobbyists "on the Hill" or media consultants and PR companies employed to spread their message.

However, there is a significant debate as to whether environmental/conservation scientists should also be advocates

E. C. M. Parsons $(\bowtie)$

Department of Environmental Science \& Policy,

George Mason University, MSN 5F2, 4400 University Drive,

Fairfax, VA 22030, USA

e-mail: ecm-parsons@earthlink.net
(Shrader-Frechette 1996; Lackey 2007; Chan 2008; Nelson and Vucetich 2009). For many scientists, the term "advocate" conjures up images of the more extreme and sensationalist NGOs, such as PETA, Sea Shepherd, or Greenpeace. For many scientists, advocacy is a dirty word, implying that by stepping out of the ivory tower, you are somehow lowering and sullying yourself, are throwing away your objectivity, or are no longer a "real" scientist. But as Noss (2007) notes, there are sloppy scientists, and there are advocates, and they are two entirely different things. But still, many scientists feel that to be involved in advocacy is somehow unethical or "against the code." Conversely, especially if you are involved in the environmental field, to stand on the sidelines and not get involved is arguably unethical. To quote Edmund Burke: "All that is necessary for the triumph of evil is that good men do nothing."

In the best sense, advocating for conservation/environmental science simply means ensuring its results get into the hands of relevant people in a format that is clearly understandable. That is not sacrificing your objectivity or integrity or being a poor scientist. It is simply communicating science to a wide and appropriate audience. As such, environmental and conservation scientists should not be afraid, as Chan (2008) neatly phrases it, to "advocate for advocacy."

So if you want to become more engaged in trying to get your research to the right ears and to turn your study findings into real environmental action, what should you do? Here are some suggestions:

1. Get help

There are lots of environmental NGOs out there; they are involved in advocacy full time. Make the most of their experience to identify whom to contact and how to contact them. They may even be interested in your work and help promote it. You need not act alone.

2. Learn to communicate

You need to get your research to the people who count, and often, this may be a busy policy maker, who 
has little or no understanding of science, who has a different world view to you, and who has a short attention span. You need to get your message over quickly, clearly, and in a way that is compelling. Scientists are often bad at this, wanting instead to discuss the details of their hypotheses, methods, and results, rather than the essential implications of the research's conclusions. Few environmental programs have classes on communication techniques, although this is changing.

3. Do not "cry wolf"

Keep to the facts and do not exaggerate. Nothing undermines your case more than being shown to be mistaken or plain wrong. Some advocates try to get attention to an issue by exaggerating the problem, perhaps to scare people into acting. But what happens when the exaggerated worst-case scenario does not happen? Keep your professional integrity, even when the other side is being unethical and may be exaggerating or overblowing its case. Your opponents may bluff that thousands of jobs may be lost, and the end of humanity as we know it is nigh if people listen to you. Do not stoop to their level. Ultimately, the most accurate advice will be remembered.

4. Be prepared to be attacked by the other side

Things may get nasty. However, I often consider that the nastier the opponents get, the more important is your message, and the weaker is their argument. Ad hominem attacks are the last refuge of the scoundrel. Your opponents are attacking the messenger because they lack a good rebuttal to the message and have to turn to trying to intimidate you instead.

5. Be prepared to be attacked by fellow scientists

Some of the nastiest attacks I have seen on scientists who have tried to advocate have been from their colleagues. The attacks rarely have anything to do with the quality of science but are often driven by misunderstanding, competitiveness, protecting funding interests, political leanings, or ego. Sadly, instead of being supportive or nurturing, the scientific community often eats its own young.

6. Stick to your guns

I was recently informed at a conference that it can take on average over 15 years to go from publicizing the science to action being taken. From my own experience, it has often taken a decade or more to go from publishing research on a problem to seeing agency action come to fruition. It may be a long, lonely road before you see policy results.

7. Keep a cool head

A logical, well informed, calm argument and defense is better than an emotional outburst. Often, your opponents will try to portray you as an emotional environmentalist, tree/dolphin/bunny hugger, and/or a poor scientist. Prove them wrong.

8. Do not let them get you down

You will likely have times when you are depressed or despairing. Even if comments and attacks are getting personal, do not take things personally. Also, do not take it home with you. Leave stresses and anxieties in the office and take time to relax and do something distracting and enjoyable. There is no need to be a martyr to your cause. But...

9. Do not do a half-hearted job

Repeated attempts to galvanize support and then dropping the ball will frustrate those trying to help or support you or get you a bad reputation. Remember Yoda: "Do or do not; there is no try."

Many times I have seen opponents, who at one time argued rabidly that I was wrong and called me a poor scientist or, worse, who, a decade later, once further scientific studies backed up what I was originally saying as true, now act as if they agreed all the time.

Many protective measures that are now commonplace and routine were once considered to be outrageous and untenable. Personally, my journey from the first raising scientific arguments and starting to advocate about an issue I thought was important, to policy being enacted, was a long, frustrating, and often nasty experience, but in the end, changes were made, and ultimately, the environment and threatened species got protections that were not there before. Despite the stress and strain, I like to think that the world is a slightly better place for me having come out of the ivory tower and taken a stance. I hope that many of you will also make the same decision and not stand idly by. We are facing many unprecedented environmental challenges caused by unsustainable human practices. Advocating for your science is not easy; you may face many trials and may not see any academic reward, but to quote Albus Dumbledore: "Dark times lie ahead of us and there will be a time when we must choose between what is easy and what is right."

\section{References}

Chan KMA (2008) Value and advocacy in conservation biology: crisis discipline or discipline in crisis. Cons Biol 22:1-3

Lackey RT (2007) Science, scientists, and policy advocacy. Conserv Biol 21:12-17

Nelson MP, Vucetich JA (2009) On advocacy by environmental scientists: what, whether, why, and how. Cons Biol 23:1091-1101

Noss R (2007) Values are a good thing in conservation biology. Cons Biol 21:18-20

Shrader-Frechette K (1996) Throwing out the bathwater of positivism, keeping the baby of objectivity: relativism and advocacy in conservation biology. Cons Biol 10:912-914 
Sutherland WJ, Adams WM, Aronson RB, Aveling R, Blackburn TM, Broad S, Ceballos G, Cote IM, Cowling RM, Da Fonesca AB, Dinerstein E, Ferraro PJ, Fleishman E, Gascon P, Hunter M, Hutton J, Kareiva P, Kuria A, MacDonald DW, MacKinnon K, Madgwick FJ, Mascia MB, McNeely J, Milner-Gulland EJ, Moon S, Morley CG, Nelson S, Osborn D, Pai M, Parsons ECM, Peck L, Possingham H, Prior SV, Pullin AS, Rands MRW, Ranganathan J, Redford KH, Rodriguez JP, Seymour F, Sobel J, Sodhi NS, Stott
A, Vance-Borland K, Watkinson A (2009) An assessment of the 100 questions of greatest importance to the conservation of global biodiversity. Cons Biol 23:557-567

Wagner GP, Walker J (2005) Citation performance analysis for the 2002 and 2003 volumes of the Journal of Experimental Zoology part B: molecular and developmental evolution. http://www.wiley.com/ legacy/products/subject/life/anatomy/JEZB_citation_ performance.pdf. Accessed 26 May 2012 